\title{
LINGUAGEM E ENSINO: SABERES LINGÜÍSTICOS E LITERÁRIOS DOMINANTES EM COMPÊNDIOS ESCOLARES
}

\author{
Ana Zandwais
}

RESUMO: The aim of this article is to discuss questions involving principles of Education during the first and second Republican governments in Brazil. We analyse contradictions between the model of education planned by workers - the Rationalist School - and the model of education adopted by the Ministry of Education during the government of Getulio Vargas. The results of this research show that as well as the educational actions, the instruments used by teachers at public schools, such as anthologies and grammars, only contribute to the reproduction of non-creative and unqualified pupils.

PALAVRAS-CHAVE: linguagem, educação, ensino, memória, xenofobia

\section{INTRODUÇ̃̃O}

Este estudo propõe uma retomada das condições históricas de produção e propagação de alguns saberes lingüísticos e literários que cir-

Ana Zandwais é professora da Universidade Federal do Rio Grande do Sul. 
culam em compêndios escolares produzidos no Brasil entre as décadas de 1930 e 1950, com o objetivo de caracterizar a realidade de ensino-aprendizagem de Língua Portuguesa durante o Estado Novo ${ }^{1}$, já que é a partir da instalação do governo Vargas que proliferam, no país, as escolas públicas e noturnas destinadas à instrução da classe proletária. A multiplicação do ensino gratuito, por outro lado, vem acarretar a proliferação de um determinado tipo de produção institucional: os compêndios de Língua Portuguesa, que visam a padronizar saberes lingüísticos e literários, vindo a caracterizar, em última instância, o modo de produção de saberes sobre a língua que identificam o contexto educacional brasileiro na $2^{\mathrm{a}}$ República.

OS ACONTECIMENTOS HISTÓRICO-DISCURSIVOS: O QUADRO EDUCACIONAL BRASILEIRO NO PROCESSO DE PASSAGEM DA $I^{a}$ REPÚBLICA PARA A REPÚBLICA NOVA

O primeiro regime republicano no país (1889-1930), já configurado, desde a sua instauração, como um cenário político de reprodução de interesses imperialistas, de hegemonias oligárquicas e rurais, bem como de franca produção de estratificações sócio-econômicas, através da exploração da força de trabalho humana, constituída por operários brasileiros e imigrantes, os quais, somando-se aos primeiros, engrossam um contingente de mão de obra que vem suprir a falta de trabalho escravo no processo de industrialização do país, pode também representar-se, por outro lado, através de um quadro descontínuo, no que diz respeito aos domínios de estratificação cultural e educacional.

Este quadro adquire uma condição de representatividade inegável no cenário brasileiro, neste período, em virtude da influência de imigrantes alemães, italianos e espanhóis, cujas perseguições ${ }^{2}$ vividas em seus países de origem passam a servir de lição tanto para a consolidação de ações políticas conjuntas formadas por operários brasileiros e estrangeiros, como de ações culturais, educativas e artísticas.

No que se refere ao campo da prática política, faz-se necessário

\footnotetext{
${ }^{1}$ Reportamo-nos ao Estado Novo não para demarcar fronteiras entre uma república velha e uma nova, conforme a descrição de alguns historiadores, mas para colocar em evidência tendências educacionais que dominaram o cenário histórico durante o regime de governo Vargas.

${ }^{2}$ Referimo-nos, notadamente, aos imigrantes anarquistas e socialistas que, vindo para o Brasil em virtude de perseguições políticas e da fuga da prisão em seus países de origem, passaram não somente a propagar ideários coletivistas entre a classe operária, mas também a constituir Ligas e Associações de trabalhadores, com o objetivo de consolidar, em território brasileiro, formas de luta e resistência para a garantia de melhores condições de vida dos segmentos proletários em geral.
} 
destacar, já em 1906, a fundação da Confederação Operária Brasileira (COB), que se constituiu no organismo de luta $^{3}$ de maior representatividade no Brasil durante a Primeira República. No que diz respeito aos campos da prática cultural e artística são fundados Centros e Teatros de Cultura Social em todo país, tendo os primeiros, notadamente, a finalidade de abordar relações controversas envolvidas em diferentes teses sociais propagadas pela literatura científica ${ }^{4}$. Já o teatro social, implantado por imigrantes anarquistas, tem como metas principais, segundo Rodrigues (1992): a) a divulgação de métodos revolucionários de educação e instrução do proletariado, tendo como uma de suas principais funções propagar teses que denunciam a desigualdade e as diferentes formas de exploração da classe proletária; b) a institucionalização de práticas de solidariedade entre os operários, servindo, inclusive, para angariar fundos à sustentação de escolas laicas, à publicação de revistas e jornais operários, bem como para a subvenção de famílias de operários desempregados ou perseguidos pelo governo em virtude de suas atividades políticas.

Por fim, o campo da educação, vinculado ao cenário cultural, adquire um prestígio ímpar para a formação intelectual do proletariado, considerando-se que é durante a Primeira República que ocorre a fundação de escolas racionalistas voltadas à formação de livres pensadores, capazes de desenvolver, conforme o Comitê Pró-Escola Moderna (1913) 5 , “ um espírito independente, racional e crítico, não se prestando para a formação de rebanhos de mansos cordeirinhos que se deixam guiar pelas ordens de um pastor". A escola racionalista, portanto, sendo uma escola para o proletariado e tendo em vista a emancipação intelectual da classe, preocupase em libertar seus alunos de dogmas religiosos, da submissão e da falta de iniciativa, valorizando, em contrapartida, a analiticidade, a relação indissociável entre os âmbitos da teoria e da prática, a oratória como meio de facilitar a liberdade de expressão individual, bem como a força do trabalho coletivo e a erradicação do analfabetismo entre o proletariado. Cabe ainda ressaltar, dentre os princípios cultivados, a convicção de que o melhor didata seria aquele capaz de formar educandos autodidatas, despre-

\footnotetext{
${ }^{3}$ A Confederação Operária Brasileira se instaura durante a realização do I Congresso Nacional Operário - 15 a 22 de abril de 1906 - que congrega representações delegadas de todas as Associações, Ligas e Federações de trabalhadores do país.

${ }^{4}$ Cabe salientar, entre os participantes ilustres que colaboraram com a proliferação dos Centros de Cultura Social no Brasil, os nomes de José Oiticica, que durante anos foi autor de uma coluna intitulada "O desperdício da energia feminina na revista "A Vida", Maria Lacerda de Moura, autora de uma coluna dedicada às ciências no jornal "A Plebe", e Neno Vasco, um dos idealizadores do Primeiro Congresso Operário e autor de artigos e peças que subsidiaram o teatro social.

${ }^{5}$ Reportamo-nos ao manifesto expedido pelo Comitê , reproduzido por Rodrigues (1992), em repúdio ao fuzilamento de Francisco Ferrer, fundador da Escola Racionalista na Espanha.
} 
zando em proveito de semelhante escolha, todo tipo de manuais, livros didáticos e práticas pedagógicas que cultivassem padrões uniformes de conteúdo e modelos de aprendizagem que, segundo as bases racionalistas, viriam a constituir-se em instrumentos oficiais de vulgarização do conhecimento científico e, portanto, de massificação cultural da classe proletária. Em outros termos, tais instrumentos utilizados por escolas públicas não deveriam ser considerados relevantes por escolas populares ${ }^{6}$, já que estes somente seriam utilizados em proveito das condições de reprodução do modo de produção de saberes segregadores e excludentes que somente atenderiam aos interesses das classes privilegiadas, como uma expressão material da violência simbólica no campo da educação.

Este contexto de lutas permanentes pela emancipação intelectual do operariado, durante a $1^{\mathrm{a}}$ República, acabou por dominar o cenário educativo, e seus resultados se tornaram concretos por meio de fundação de escolas racionalistas em todo país, dentre as quais destacamos as Escolas Modernas n ${ }^{\circ} 1$ e 2 de São Paulo, criadas em 1909, as Escolas Modernas do Ceará e de Petrópolis, a Escola Operária $1^{\circ}$ de Maio de Vila Isabel (RJ), inaugurada por José Oiticica ${ }^{7}$, e as Escolas Modernas Instituto de Educação e Ensino Racionalista e Elyseu Reclus, fundadas em Porto Alegre.

Contudo, como o movimento operário passa a desagregar-se consideravelmente em virtude de dissensões entre as alianças anarquista, anarcossindicalista e socialista, sobretudo, a partir da década de 20, após fracassos em greves que sucederam as grandes greves gerais de $1917 \mathrm{e}$ 1919, também os projetos de emancipação cultural e educacional passam a sofrer as consequiências dos obstáculos que os acontecimentos históricos imputam à classe proletária. Deste modo, não obstante as críticas feitas por lideranças políticas do movimento, e quiçá também por uma condição de "perda do sentido" do futuro, as articulações político-proletárias somente resistem no que tange à manutenção de interesses de ordem econômica, ficando "ao abrigo da sorte" as prospecções de ordens cultural e educacional, as quais somente sobrevivem através da luta insistente de algumas militâncias convictas da importância de vincular à luta econômica outras expectativas futuras para o operariado, conforme ilustramos com recorte de uma análise feita por um dos defensores ${ }^{8}$ do processo de rearticulação da consciência do movimento proletário.

${ }^{6}$ A referência a escolas populares remete a uma proposta educacional com vistas à emancipação intelectual do proletariado.

${ }^{7}$ Cabe ressaltar ,aqui, que durante suas peregrinações entre os Círculos operários, o Prof. José Oiticica costumava proferir palestras sobre temas sociais, literários e lingüísticos, dada a sua ampla formação acadêmica em jornalismo, Letras e Medicina

${ }^{8}$ Referenciamos o artigo "Problemas de reorganização" de Astrogildo Pereira, publicado no jornal "A Plebe" em 1921. 
“... O ambiente brasileiro aparece aos olhos do menos perspicaz observador como um ambiente mais desfavorável do que favorável ao desenvolvimento da organização obreira. Somos um país sem tradição de luta proletariana.... O analfabetismo, a ignorância integral das massas, mantêm-nas longe do contato das correntes contemporâneas de reivindicação social... Sim, que se abram as escolas possíveis, para crianças e adultos. Mas este será apenas um meio subsidiário, secundário de combate à ignorância do ponto de vista da organização..." (A Plebe, 11.06.1921, p.2)

Deste modo, tendo em vista não somente os obstáculos econômicos, as coerções políticas mas também as cisões internas, no que tange a definições sobre um perfil de projeto político coletivo para emancipar o proletariado, o quadro que passa a dominar o cenário das práticas proletárias pode ser caracterizado, já no início da década de 30, como um forte contexto de divisão entre organizações operárias e tendências de ação, luta e resistência. É, pois, em meio a essa fragilização, em parte determinada por forças políticas externas, e em parte determinada pela ausência de expectativas de articulação interna que as forças proletárias, frustradas e sem expectativas, passam a constituir-se em objeto de conquista da junta de governo Vargas ${ }^{9}$ que, ao tomar o poder, legitima seu espaço por meio de um discurso de aliança com os trabalhadores brasileiros, dando ênfase, fundamentalmente, ao término da exploração da força de trabalho do operariado e ao combate às forças internacionais e oligárquicas. Cabe salientar, aqui, por outro lado, que se alguns autores ${ }^{10}$ atribuem ao governo Vargas, de forma lúcida, uma posição ambígua por controlar simultaneamente os segmentos oligárquicos e as forças revolucionárias no país, é inegável a constatação de que este regime de governo passa a obter a adesão dos movimentos populares que se articulam aos projetos políticos do Estado Novo, fortalecendo, em última instância, as condições de formação de uma formação discursiva (fd) populista, a qual instaura, entre outros saberes, o saber de que a emancipação do proletariado deveria advir de concessões promulgadas pela classe governante aos trabalhadores e não da luta direta das massas. Esta fd, por outro lado, encontra respaldo no campo da ação política, em relação aos saberes que se propõe a consolidar, através da fundação do Ministério da Saúde, Trabalho, Indústria e Comércio, e do Ministério da Educação, sendo também promulgadas, em 1934, leis que regulamentam as questões educacionais no país. Assim, se o princípio que

${ }^{9}$ Fazemos referência ao golpe de Estado de 1930, que desencadeia a instalação de uma junta de governo no país.

${ }^{10}$ Reportamo-nos aos textos de Vianna (1970),Weffort (1980) e Pellanda (1986). 
ilustra o saber de que a emancipação proletária não se obtém por meio de lutas, mas através de deliberações externas, é paradoxal, o imaginário, as consequiências que ele impõe, atestam certas evidências como o enfraquecimento da autonomia das forças proletárias e a crescente possibilidade de "minar o campo da resistência popular", através da absorção de interesses coletivos que passam a ser deliberados pelo aparelho estatal. Desta forma, se ao revés de desencadear um processo emancipatório, a criação de um Ministério do Trabalho seria uma das formas de atrelar as forças sindicais ao poder de controle estatal, os discursos de aliança entre a fd. populista e as forças populares passam a refratar essa realidade. Do mesmo modo, pode-se caracterizar o fato de que a multiplicação de instituições escolares destinadas à classe operária viria a reforçar uma posição paternalista do Estado, em relação ao processo de formação educacional do proletariado.

Não obstante a inconveniência um tanto constrangedora dessas contradições, articuladas em torno de um discurso de aliança, uma evidência precisa ser tomada como incontestável: o fato de que através do discurso de "democratização" do ensino às classes trabalhadoras é que passam a ser retomados projetos, os quais teriam se resumido a utopias, em virtude das dissensões internas entre as forças proletárias. É, portanto, na relação inversa das expectativas das lideranças proletárias que os interesses dos trabalhadores passam a ser absorvidos e também, contraditoriamente, atendidos pelo aparelho estatal.

É ainda em virtude desse "estreitamento" dos efeitos dos saberes e da ação populista sobre as expectativas das forças proletárias, absorvidas pela prática política dos primeiros, que faz-se possível dar destaque a um domínio de saber aparentemente comum às fds operária e populista: a necessidade de propiciar o acesso à instrução a todos aqueles excluídos da instituição escolar. Esse domínio de saber, por outro lado, concretiza-se como ação política do Estado através: a) da multiplicação de instituições de ensino gratuitas; b) da contratação de docentes qualificados ou mesmo leigos para ministrar disciplinas nas escolas públicas; c) da prática de elaboração de programas curriculares com o objetivo de normatizar as condições de ensino da escola pública; d) do incentivo à produção de manuais e compêndios escolares com vistas a "facilitar" a ação pedagógica.

Pode-se constatar, portanto, que é situada em um terreno mais propriamente antagônico do que contraditório que a classe trabalhadora passa a ter "direito amplo" à instrução gratuita. É, pois, em consequiência da absorção de domínios de saberes do discurso-outro, daquilo que consagra a memória da organização operária brasileira, que as ações práticas do governo Vargas passam a deliberar a respeito de um novo futuro para o sujeito operário: isto é, passam a representá-lo como um sujeito mantenedor 
da ordem social vigente, porquanto o Estado lhe concede direitos pelos quais ele não mais precisa lutar. Assim, ao abrir mão de práticas de resistência e de luta, no campo político, o sujeito operário simultaneamente abre mão de questionamentos sobre os princípios que viriam a nortear as ações de qualificação cultural, educacional e profissional da classe, para, enfim, concretizar-lhe um novo futuro.

Se as contingências históricas permitem caracterizar o modo como o sujeito operário deixa-se representar a partir dos discursos que lhe conferem espaços no interior da fd. populista, é importante também que analisemos as peculiaridades das ações institucionais no campo da educação, a fim de podermos estabelecer relações transversas entre o modo como este sujeito é representado e as ações que passam a qualificá-lo. E para fazê-lo tomamos como fio condutor dessas relações uma investigação dos meios através dos quais se processam as práticas de oficialização do ensino público no domínio dos estudos da linguagem.

\section{DOS PROGRAMAS DE ENSINO, LIVROS DIDÁTICOS E PRÁTICAS} PEDAGÓGICAS

Conforme Nascentes (1935), a uniformização dos programas de ensino do Idioma Nacional ${ }^{11}$, que constam na apresentação dos compêndios gramaticais e antologias, deve-se, fundamentalmente, à criação de diretrizes norteadoras dos estudos da linguagem que devem regular os domínios de conhecimentos comuns presentes nestes programas ${ }^{12}$, bem como os objetivos implicados na aquisição de tais conhecimentos, conforme arrolamos a seguir: I) Leitura: com o objetivo de prover o indivíduo da capacidade de ler com compreensão, desembaraço e rapidez; II) Literatura: com o objetivo de propiciar ao aluno um passatempo agradável e, sobretudo, oferecer-lhe modelos de referência para seus trabalhos, além de vocabulário; III) Gramática: tornar o aluno sensível às incorreções da linguagem oral e escrita e, conforme Nascentes (1935, p.35), para evitar a reprodução da linguagem dos incultos e até mesmo do ambiente de origem, já que, segundo o autor, "muitos alunos da escola pública podem provir de meio inculto"; IV) Composição: com vistas a desenvolver, no aluno, a capacidade de escrever com clareza, correção e elegância na escola ou em qualquer

\footnotetext{
${ }^{11}$ Co-designação conferida à Língua Portuguesa, dominante nos títulos de compêndios escolares e antologias, tendo em vista o objetivo de dar visibilidade à língua como patrimônio nacional.

${ }_{12}$ Antenor Nascentes foi designado no período de 1930 a 32 como relator de Comissão de Instrução Pública, a fim de deliberar a respeito: a) da adoção de uma nomenclatura gramatical unificada; b) do padrão ortoépico da Língua Portuguesa; c) das diretrizes norteadoras dos estudos da linguagem.
} 
circunstância; V) Escrita e Caligrafia: com o objetivo de desenvolver as habilidades de escrever com rapidez e facilidade.

É, pois, a partir de tais diretrizes que se faz possível entender a condição de uniformidade dos programas oficiais, presentes nos compêndios e que, salvo a distribuição de excertos e de conteúdos gramaticais em diferentes séries, de acordo com dificuldades previstas, compõem-se de matérias comuns. A ação propulsora que sustenta, portanto, a uniformidade dos compêndios escolares, fragmentados em conteúdos gramaticais, seletas de textos literários, exercícios de leitura e análise gramatical, é não somente de ordem institucional, mas também autorizada por representantes ilustres da área de estudos da linguagem ${ }^{13} \mathrm{e}$ autores de compêndios, embora alguns autores como Nascentes (1935) e Mota (1941) tenham formulado duras críticas ao caráter reprodutório das antologias e à complexa nomenclatura presente nos compêndios gramaticais. Deste modo, é a partir da elaboração de um projeto nacional de referência para a adoção de programas de ensino que se consagram, já na instalação do Governo Vargas, as bases para a definição de disciplinas a serem ministradas, nas escolas, na área de estudos da linguagem.

Cabe observar, por outro lado, que se o processo de uniformização do que se ensina/aprende em matéria de linguagem produz um efeito de homogeneidade que, aparentemente, parece silenciar as diferenças entre os indivíduos, em termos instrucionais, fundamentalmente em virtude de: a) um número expressivo de livros didáticos apresentarem a mesma sistemática de elaboração; b) os programas de ensino serem padronizados; c) os compêndios privilegiarem, de modo uniforme, os estudos morfológicos e a análise lógica das estruturas da língua; d) os exercícios de leitura e compreensão de textos darem ênfase, além das questões gramaticais, à apropriação de itens lexicais representativos do uso culto e às suas condições de emprego em textos literários. A própria condição de observar os modos como se abordam e operacionalizam os conteúdos, em termos práticos, no livro didático, já nos permite caracterizar o fato de que, embora sejam utilizados pela escola pública, estes não atendem aos interesses da clientela a que se destinam, nem possibilitam estimular a criatividade ou o auto-didatismo, já preconizados pelo ideário da escola racionalista.

A fim de tornar mais específicas as considerações feitas, passamos a caracterizar alguns aspectos do tratamento dado, por livros didáticos, a questões gramaticais, literárias e de composição.

${ }^{13}$ Referimo-nos, notadamente, a Laudelino Freire e Torres (1944), como membros das Academias Brasileira e Fluminense de Letras e a Léllis, na qualidade de docente da Pontifícia Universidade Católica do Rio de Janeiro. 


\section{Questões de Ensino de Gramática}

Um exame preliminar dos compêndios gramaticais torna possível observar que o padrão dominante de apresentação dos estudos de gramática, nos compêndios, pode ser identificado, primeiramente, através da sequienciação de conteúdos fonéticos, morfológicos e sintáticos, estudados de forma separada dos excertos, embora os exemplos utilizados para caracterizar questões de sintaxe, notadamente, sejam abstraídos de textos literários, com ou sem referência a sua autoria ${ }^{14}$, conforme ilustramos com os recortes, a seguir, a respeito do emprego do pronome relativo:

"O pronome relativo que ou faz função de sujeito ou de objeto; raramente de atributo."

Ex: A ventura dos maus tem o brilho e a duração do relâmpago que precede e anuncia o raio" (MOTA, 1941, p.97)

"Emprega-se que como pronome subjetivo, objetivo e terminativo." (CARVALHO, 1940, p.88)

Subjetivo

Ex: "Se a cólera que, espuma, a dor que mora n'alma e destrói cada ilusão que nasce." (R. CORREA)

Objetivo

Ex: “Este é meu conceito, o quinhão que me dá fortuna” (DEMÓSTENES)

A ilustração dos exemplos acima quer colocar em destaque, dentre as polêmicas que podem suscitar para o leitor, não somente a ausência de princípios capazes de justificar divisões entre os pronomes objetivo e subjetivo, mas também equívocos como a afirmação de que o pronome relativo raramente possui função atributiva. Esta questão coloca em perspectiva, para nós, o fato de que ao tomar o pronome relativo apenas como uma classe gramatical isolada de seu funcionamento, os autores ignoram o fato de que, mesmo no âmbito oracional, a oração relativa funciona anafórica e atributivamente em relação aos antecedentes aos quais se articula.

Ainda com relação ao estudo deste mesmo pronome, com base na leitura de excertos, observamos em Léllis (1950) que é a partir do aproveitamento de um conto, utilizado para análise sintática, que o autor propõe ao aluno que identifique as funções do pronome que, independentemente de qualquer outro tipo de reflexão decorrente da atividade classificatória.

${ }^{14}$ Reportamo-nos a Mota (1941) que não somente se utiliza de conhecimentos da teoria da correlação sem referenciar Oiticica, mas também omite a autoria dos exemplos com os quais ilustra questões sintáticas. 
Cabe observar também, complementando os comentários acima, que uma análise dos livros didáticos selecionados para este estudo possibilitou-nos constatar que o modo de formulação dos exercícios não escapa a um padrão mais ou menos reprodutivo ${ }^{15}$. Somados aos exercícios de identificação de funções sintáticas e classes gramaticais, encontramos, predominantemente, exercícios classificatórios, de fixação de estruturas a partir de um modelo, de caracterização ou decomposição de palavras derivadas ou compostas, ou ainda de preenchimento de lacunas, em frases, com diferentes classes gramaticais.

Paralelamente, aos exercícios gramaticais que decorrem dos excertos, pode-se colocar também em destaque a opulência lexical que se desdobra em glossários ao final de cada texto, independentemente de que sejam exploradas suas condições de uso em qualquer contexto. Desse modo, servindo muito mais à formação de um "espírito enciclopédico" do que a fins práticos, os itens lexicais e elementos gramaticais passam a servir de instrumentos de manutenção da tradição literária, construindo um imaginário elitista que divide os sujeitos no interior de sua própria língua, promovendo, desse modo, a exclusão daqueles que não dominam padrões estéticos de escrita. Paralelamente, os modelos de rejeição à xenomania, vêm corroborar a condição fictícia de homogeneidade da língua, e, portanto, dos falantes, condição esta, própria das políticas populistas que, para produzirem um efeito de identidade nacional, dissimulam as condições históricas de hibridez étnica e cultural de um povo e sustentam suas contradições com base em um discurso de homogeneidade lingüística; isto é, o ideal de língua passa a ser "uma língua inteligível porque comum para todos, uma língua "ecumênica" indiferente aos falantes, embora estes nunca sejam indiferentes a ela. Eis porque sua sustentação sob a base de um sistema gramatical e de um inventário lexical tornam-se fundamentais, porquanto apagam as condições reais de sua heterogeneidade.

As perspectivas de Machado Filho (1953) e de Adrião (1943), cujos comentários transcrevemos a seguir, talvez elucidem, de forma mais empírica, nossa abordagem.

"No século XIX, bom número de escritores portugueses e brasileiros, reagindo brilhantemente contra os estrangeirismos, as inovações descabidas, o abastardamento da língua e o mau gosto reinante, inspiram-se nos bons autores antigos e apresentam com as roupagens do estilo moderno, as galas e as riquezas da antiga linguagem... No século $\mathrm{XX}$, a reação anterior continua, grandes filólogos terçam armas em prol da corre-

${ }^{15}$ Nesta fase inicial da pesquisa foram analisados oito livros didáticos, considerando-se a notoriedade de seus autores e o número de edições a que deram origem. 
ção e magnificência do idioma. Quem quer escrever corretamente a língua não pode aceitar de mão beijada, quantas inovações por aí apareçam nas gazetas e na literatura, que são às vezes estrangeirismos inúteis e pedantes, filhos da ignorância dos recursos do vernáculo e de uma ridícula e desfrutável xenomania" (ADRIÃO, 1945, p. 30-1)

A título de ilustração de seus comentários, Adrião apresenta trechos de obras de Gonçalves Dias e de discurso de Rui Barbosa com o objetivo de ratificar a importância da manutenção da "pureza" da língua, observando, por outro lado, que "não há escritor, por mais profundo conhecedor da língua, que não tenha uma vez ou outra seus deslizes"(ibid., p.28). Assim, ao transcrever um trecho de Gonçalves Dias como "Também não me lembra... porque razão da morte me queixo, que vejo e não vê-me tão sem compaixão", censura ao autor por utilizar a ênclise em verbo de modo finito, após a negação. Já ao transcrever um trecho do discurso de Rui Barbosa como “.... o registro do gás para assassinar o povo indefeso e afogar em sangue os meetings abolicionistas”, censura-o por utilizar um anglicismo ao invés de comício.

Já Machado Filho (1953, p.166), ao tratar da influência de estrangeirismos no uso corrente da Língua Portuguesa condena tanto os galicismos sintáticos quanto o emprego de expressões apropriadas do léxico francês. Com relação ao emprego de preposições, critica o emprego de $a$ ao invés de para, por, exemplificando seus comentários com formas correlatas (1) "questão por resolver" (1') “questão a resolver", onde a última é rejeitada com base nos argumentos que seguem: “... um dos piores vícios do falar hodierno é o uso falso das partículas, e especialmente da partícula a, uso todo baseado no francês, e introduzido entre nós pelos galicizantes."

Ainda com relação ao tratamento dos vícios de linguagem, dentre os solecismos, barbarismos, cacofonias, cabe dar destaque a uma questão: a anfibologia ou ambigüidade ${ }^{16}$. É importante ressaltar que, na medida em que os compêndios, em geral, ignoram questões de natureza semântica, contrariamente à perspectiva adotada para os componentes morfológico e sintático da língua - unificação da nomenclatura gramatical - não há critérios definidos para o tratamento de questões de ambigüidade. Assim, alguns autores, ao abordarem a questão da ambigüidade, tratam-na como um fato decorrente do "mau emprego" de estruturas da língua como em (2) "A imagem de Júpiter pintava-se com um raio na mão"; (2') “ Tenho um livro lido" ${ }^{17}$. Outros, tratam-na como confusão decorrente de cruzamentos

\footnotetext{
${ }^{16}$ Conforme Carvalho (1940, p.219).

${ }^{17}$ Exemplos apresentados por Sequeira (1953, p.71-80).
} 
lexicais, vícios que devem ser extintos, como em : (3) "Nesta seríssima conjectura fostes vós indicado há pouco...." ${ }^{18}$.

Em decorrência das considerações acima, portanto, pode-se concluir que o tratamento da ambigüidade, como efeito de cruzamentos sintáticos ou lexicais acaba se revelando mais como um simples critério formal, com vistas a excluir o erro com base no método, do que como uma reflexão a respeito do processo histórico da língua, as condições de produção de sua hibridez, e dos movimentos para os quais o sentido conduz nas relações que o sujeito mantém com a linguagem. Esta evidência, por outro lado, também nos permite constatar que se a ausência de critérios semânticos, no tratamento dado à língua pelos compêndios, obriga os autores a configurarem a dispersão dos sentidos como cruzamentos, vícios, não há, nesses manuais, senão a perspectiva de tratar da língua como um objeto desvinculado de toda e qualquer injunção histórico-social, do campo da práxis, e, portanto, regulado por um discurso de normatividade e isento de interpretações.

\section{Os excertos: as práticas de leitura e interpretação}

Se os programas oficiais de ensino são constituídos por componentes comuns, a apresentação de antologias, nos compêndios, também visa a objetivos mais ou menos uniformes como: a) reunir textos clássicos de diferentes gêneros e épocas, para ilustrá-los como padrões estéticos; b) caracterizar a opulência de recursos lexicais do vernáculo através da apresentação de glossários e de notas explicativas ao final dos textos; c) relacionar o conteúdo dos excertos a padrões normativos, questões de gramática e de análise lógica, através de exercícios propostos ao final de cada texto, ou ainda em capítulos anteriores que fazem referência às seletas de textos correspondentes a diferentes séries; d) explorar a capacidade de compreensão de leitura dos alunos, através de exercícios "interpretativos". Por outro lado, a seleção de textos que compõem as antologias visa ao atendimento da solidificação de um imaginário de língua que nada apresenta de comum com o campo heterogêneo das práticas sociais que configuram a clientela a que os livros didáticos atendem.

Em relação ao modo de organização das seletas de textos que figuram tanto nos compêndios como nas antologias ${ }^{19}$ são apresentados di-

${ }^{18}$ Exemplo em que ocorre, segundo Potsch (1954, p.207), cruzamento entre conjectura e conjuntura.

${ }^{19}$ Cabe observar que a tradição de elaborar antologias de forma separada das gramáticas é anterior à prática de produção de compêndios escolares, remontando às práticas pedagógicas da $1^{a}$ república. 
ferentes gêneros que abrangem a prosa, a poesia, trechos de romances clás$\operatorname{sicos}^{20}$, regionalistas e até mesmo o gênero epistolar, que segundo os autores dos compêndios, constitui-se em um excelente modelo para motivar a composição de correspondências, embora duramente criticado por Nascentes, conforme transcrevemos a seguir:

Grave condenação merecem também os livros de descrições e cartas. Não é copiando modelos servilmente que alguém aprenderá a redigir. Estes livros protegem a indolência, bestificam o aluno. Regala-se com eles a mediocridade. (NASCENTES, 1935, p.81)

No que diz respeito aos temas que se reiteram nas antologias, predominam, desde uma perspectiva sincrônica, temas cívicos, recobertos por textos que versam sobre pátria, nacionalidade e língua; temas morais, ilustrados com juízos, através de textos como fábulas, lendas e até mesmo de sequiências de provérbios utilizados para interpretação; temas religiosos que abundam em diferentes gêneros, tais como a prosa, a poesia e o gênero epistolar. ${ }^{21}$

Faz-se necessário colocar em destaque, ao mesmo tempo, o fato de que a repetição de determinados temas, em um mesmo compêndio, não somente contribui para a cristalização de determinados saberes que devem ser apreendidos dominantes, conforme Achard (1999, p.13), mas também para a ratificação de outros saberes que, embutidos nos conteúdos dos textos, são retomados para que sobrevivam como paráfrases que zelam pela tradição de um imaginário de reprodução da desigualdade, historicamente construído, e que deve regular o senso comum. Com o objetivo de ilustrar o modo como tais saberes aparecem embutidos e guardam a "tradição", neste caso, da equivalência entre desigualdade econômica e cultural, recortamos de dois compêndios textos que tratam sobre o aprendizado da língua materna:

Ouvindo gente correta, lendo escritores esclarecidos, é possível e mesmo provável a dupla correção no escrever e no falar. Em tese, o filho de pessoas eruditas fala com o necessário acerto; e o oriundo de pais incultos, por maior que lhe seja a idade e estudo, sustenta distraído o eu vi ela "a vida inteira". (BITTENCOURT in: CARVALHO, 1940, p.77)

Abre teu livro. Que vês nele? Letras, simples sinais: material

\footnotetext{
${ }^{20}$ Reportamo-nos, notadamente, a trechos de obras de José de Alencar, Guimarães Rosa, Gonçalves Dias, Casimiro de Abreu, Olavo Bilac, Almeida Garret e Pe. Antonio Vieira, que se reiteram nos compêndios analisados..

${ }^{21}$ Cabe dar destaque à reprodução de correspondências de ilustres representantes clericais, cuja finalidade consiste em apresentar motivos para a elaboração de composições.
} 
poderoso com que constrói obra mais sólida do que a do pedreiro. O que o pedreiro, com todos os materiais não pode edificar, fá-lo o sábio só com as letras. (COELHO NETO in: TORRES, 1944, p.131)

Em relação às práticas de interpretação ${ }^{22}$ nas antologias e compêndios gramaticais, observamos que são apresentados questionários que exploram questões puramente gramaticais, em que o aluno precisa saber identificar, por exemplo, quais "as formas do pronome possessivo que correspondem à $1^{\mathrm{a}}, 2^{\mathrm{a}}$ e $3^{\mathrm{a}}$ pessoas" ${ }^{23}$, diferençar verbos que apresentam predicações incompletas daqueles que possuem predicação completa, caracterizar a função sintática dos pronomes e assim por diante. Já os questionários que acompanham os textos literários, embora apresentados como questões de interpretação, reduzem-se a meros exercícios em que o aluno precisa responder questões que estão literalmente postas no conteúdo dos textos. Deste modo, salvo a apropriação de novos itens lexicais, as práticas de leitura e interpretação caracterizam-se, em última instância, como meros exercícios mnemônicos, em que a condição suficiente para aprender a ler consiste em transportar conteúdos, reproduzi-los, independentemente de qualquer possibilidade de relacioná-los com outros similares, ainda que os excertos apresentem múltiplos textos versando sobre os mesmos temas, sendo, assim, descartada toda possibilidade de questionamentos sobre o próprio conteúdo dos textos apresentados como "motivação" para leitura.

\section{Sobre a composição}

A prática de produção de textos, designada como composição por antologias e compêndios gramaticais, embora aparentemente não se apresente de modo uniforme, podendo complementar exercícios de interpretação elencados após seletas de textos ${ }^{24}$, ou ser proposta em secção à parte, intitulada "motivos para composição" ${ }^{25}$, ou ainda integrar um apêndice do livro escolar, juntamente com questões de estilística, como ocorre em Pereira (1940), pode configurar-se como um dos aspectos da área de estudos da linguagem mais duramente criticados por Nascentes (1935, p.103). Segundo o autor, as práticas de composição geralmente incorrem em exercícios de "gramatiquice", propostos a partir de temas artificiais que em nada concorrem para desenvolver a capacidade reflexiva do aluno.

\footnotetext{
22 Designação adotada, de modo geral, por compêndios e antologias.

${ }^{23}$ Conforme podemos constar em Mota (1941).

${ }^{24}$ Conforme a proposta de Torres (1944), a composição deriva de exercícios de interpretação que acompanham os textos.

${ }^{25}$ Conforme faz Mota(1941).
} 
Para Nascentes, a escrita deve responder às necessidades de expressão do aluno, de modo que os meios de expressão não podem ser entendidos como meras "categorias formais e sem nenhum valor prático" como ocorre com as gramáticas. Não poupando suas críticas ao modo como os compêndios e antologias deixam de responder aos objetivos de ensinar a escrever, Nascentes observa com sarcasmo que "... o que Machado de Assis não sabe fazer, exige-se por aí nas escolas públicas que o façam as crianças, convidando-as à banalidade mais tediosa, aos chavões e arrebiques de estilo mais cediços, com que satisfazem ao gosto deplorável de alguns mestres..."

É, pois, considerando o ceticismo de Nascentes que, na qualidade de membro da Comissão de Elaboração das Diretrizes de Ensino da área de Estudos da Linguagem, deveria abonar as propostas de inserção de práticas de escrita em livros didáticos, e não o faz, que passamos a caracterizar as condições em que a composição é proposta nos livros analisados

Em Carvalho (1940, p.9), a composição ou é proposta a partir da leitura de excertos ou como uma atividade, à parte, em que o aluno precisa descrever ou narrar. A primeira proposta pode ser elucidada, por exemplo, por uma situação em que após a leitura de uma narrativa sobre o conteúdo de um texto epistolar, escrito pelo General Osório, cujo teor consiste em avaliar as más condições de cavalos que seriam vendidos ao governo, e que é concluída com uma reflexão sobre o valor da dignidade humana, o autor propõe, ao aluno, que reproduza o conteúdo do texto com alterações de formas de tratamento. Assim, a prática de composição fica reduzida a um mero exercício de mudança pronominal, sem que sejam questionadas relações entre valores éticos e ações pragmáticas.

No que diz respeito à segunda proposta, o autor define os cenários que o aluno deve descrever a partir de delimitações prévias dos objetos que compõem tais cenários. Deste modo, ao propor a descrição de uma tempestade na floresta (ibid., p.237), o autor fornece-lhe os referentes como "o toldar-se o céu, os relâmpagos, o vento, as primeiras gotas, a corrida das aves e seus ninhos, seus pios aflitos, o barulho das árvores que se curvam...", de tal sorte que ao aluno resta somente inseri-los em sua descrição, sem descuidar que alguns destes referentes sejam excluídos.

Já em Mota (1941, p.241), encontramos motivos para composição em modelos de discursos extraídos da literatura e da bíblia e em modelos de cartas dirigidas por elites intelectuais portuguesas a autoridades imperiais e eclesiásticas, bem como epístolas que configuram o modo de circulação de saberes religiosos em discursos de evangelização. ${ }^{26}$ É in-

\footnotetext{
${ }^{26}$ Reportamo-nos às epístolas de S. Pedro e S. Paulo.
} 
teressante observar que o que se pode encontrar de comum nesses textos, além do fato de serem predominantemente dirigidos a destinatários ilustres, são trechos e ditados em Língua Latina, os quais são apresentados como mote para a produção de outros textos, de tal modo que o aluno, ao ler tais ditados deve não somente reproduzir os temas dos trechos latinos em sua composição, mas também o estilo retórico dos modelos discursivos apresentados. Por conseguinte, ficariam, então, a seu critério de escolha, talvez, as designações imaginárias das qualificações de autoridades para serem ilustradas como destinatários prováveis de seus textos. Este tipo de prática, portanto, ao cercear os espaços para a criatividade do aluno e afastálo da realidade cotidiana, acaba por produzir um efeito inegável de que o exercício da composição deve ser uma prática fictícia ou um exercício de mera retórica, onde o que está em jogo não é a interlocução, a reflexão, a criatividade, mas o modo como se pode dispor de recursos vernaculares, com função puramente estética, e da correção gramatical para escrever.

Se a constatação de tais realidades nos permitiu transformar as dúvidas que tínhamos sobre a condição reprodutivista das práticas de composição em certeza, buscamos, por outro lado, observar também como é apresentado o exercício da escrita em um compêndio para o ensino superior. ${ }^{27}$ Verificamos, então, que em um apêndice do livro que trata sobre sintaxe e estilística (1940, p.391) são desenvolvidos pressupostos norteadores do estilo e da composição.

Em relação às condições apresentadas como necessárias à obtenção do estilo, o autor enumera as que seguem: a) nobreza, que consiste em caracterizar textos de estilo puro, sendo evitadas expressões triviais e plebéias, bem como as cacofonias; b) correção, que obedece às regras da gramática, descartando solecismos e barbarismos; c) clareza, que deve refletir a nitidez do pensamento, sendo condenados à falta de clareza o uso de arcaísmos, neologismos, provincianismos e, fundamentalmente, a anfibologia; d) precisão, que deve ajustar as palavras às idéias, sendo evitada a difusão redundante de palavras (prolixidade) e a impropriedade de termos.

Conforme se pode observar acima, as propriedades estilísticas que delimitam o exercício da escrita privilegiam, conforme Orlandi (1996), a representação de um imaginário de língua asséptica, livre de todas as influências externas, quer do sujeito ou da história, como da anfibologia, da xenomania, dos arcaísmos, neologismos e até mesmo do plebeísmo, tratado como proselitismo inútil, porquanto retrata o comportamento lingüístico do falante de classe social baixa que não domina o repertório

${ }^{27}$ Reportamo-nos à Gramática Expositiva de Eduardo Carlos Pereira (1940). 
lexical "clássico". Assim, se o processo de ensino da escrita deve também ser dirigido para o sujeito proletário, a escola ensina-o dizendo-lhe explicitamente, através dos compêndios com os quais explora o vernáculo, que tanto sua forma de expressão é equivocada, como sua linguagem deve ser ignorada. Oferece-lhe, em contrapartida, um lugar "seguro", um imaginário de escrita baseado em uma concepção de hiperlíngua ${ }^{28}$ que somente pode ser concretizado como prática através do domínio estrito de constituintes gramaticais, lexicais e recursos de oratória. Ao jogar, enfim, com um imaginário de língua que procura denegar as diferenças de padrão ou de recursos de linguagem, dos quais os sujeitos oriundos de diferentes classes lançam mão para expressar-se, ao domesticar a própria condição de opacidade do sentido, por tratá-lo como um caso de anfibologia, e ao refrear as múltiplas possibilidades de gestos de interpretação do modo como a matéria significante - a própria exterioridade social e histórica - pode ser representada através do objeto lingüístico, os compêndios escolares acabam por esfacelar toda e qualquer possibilidade de trabalho com a língua, enquanto uma materialidade empírica dotada de sentidos e, portanto, capaz de refletir representações identitárias heterogêneas de sujeitos reais, e não forjados, oriundos de contextos sociais distintos, e, por isso, investidos tanto de interesses quanto de gestos de interpretação contraditórios, em face das histórias/memórias que os significam e do modo como utilizam a língua para simbolizá-las.

\section{POLÍTICA DE ESTADO E POLÍTICA EDUCACIONAL NO ESTADO NOVO: UM PROJETO POPULAR OU DE CONTROLE?}

Se as ações políticas do Estado Novo infundiram no sujeito proletário expectativas de retomada de projetos que viriam ao encontro do ideal de transformação de uma sociedade desigual em uma sociedade liberta dos estigmas da exploração econômica e da segregação cultural, tais sentimentos não foram alimentados senão em razão de um jogo contraditório de forças de exclusão/dominação. De um lado, as significativas cisões entre as forças políticas proletárias, que acarretaram um sentimento crescente de perda de espaços de resistência e de luta. De outro, a constituição de um Estado "messiânico", apresentado como defensor das causas operárias, onde os direitos trabalhistas são institucionalizados e o acesso à educação é facultado a todos, sem distinção de classe ou etnia. Um Estado,

\footnotetext{
${ }^{28}$ Conforme a exposição de Auroux (1995) a respeito da noção de hiperlíngua, entendida como um saber que possibilita explicar as condições que determinam a adoção de determinados pressupostos de língua e de gramática.
} 
portanto, capaz de se reconhecer como "revolucionário" e de propagar, por meio de seus saberes, o reconhecimento das aspirações do povo pela democracia, pela igualdade de direitos e pela unidade entre as etnias. ${ }^{29}$ Mas, ao mesmo tempo, capaz de fazer circular, por meio de seus discursos e de suas leis, saberes opostos à causa da emancipação proletária, quer no campo político-partidário ${ }^{30}$, quer no campo da educação. Assim, ao interpelar as massas na condição de "pai dos pobres", mas não de padrasto, o governo Vargas consegue neutralizar tanto as ações grevistas das militâncias sindicais e populares, como as forças de resistência aos princípios que determinam as condições de propagação de suas ações estratégicas. Finalmente, no que diz respeito ao campo educacional, tratado, neste estudo, com ênfase em questões de ensino do Idioma Nacional, pode-se constatar que o efeito mais visível de apagamento da memória histórica, enfim, da identidade do sujeito proletário, se dá através da relação deste sujeito com os ensinamentos que circulam na escola e que se reiteram nos compêndios escolares. Isto é, se o trabalho de significação, conforme Orlandi (1998), não escapa à relação que o sujeito mantém com a língua, as reflexões determinadas pelos compêndios e antologias, ao excluírem, das práticas de interpretação e de escrita, as condições de subjetivação heterogêneas do sujeito, através de diferentes modalidades de assepsia de marcas de subjetividade, tais como a anfibologia, os empréstimos, o plebeísmo, as formas de construção indiretas, os paralelismos, a prolixidade, etc..., determinam, por fim, um efeito de apagamento da identidade do sujeito através das relações que ele aprende a estabelecer, na escola, com a própria língua. Não restam dúvidas, por outro lado, que ao nos depararmos com tais práticas, estamos nos deparando com uma forma específica de racionalidade. Entretanto, semelhante tipo de lógica, ao contrário do que se propunham as escolas racionalistas, durante a Primeira República, vem ao encontro de um projeto de formação de sujeitos que se moldam a partir de um padrão de referência identitária, através do modo como os saberes dos quais devem apropriar-se/desapropriar-se passam a qualificá-los ou desqualificálos perante a sociedade e perante o Estado. Assim, à semelhança da massa, da argila e das esculturas que se modelam para produzir determinados efeitos, o sujeito proletário aceita os "benefícios" educacionais que lhe são ofertados, sem entender que o caráter de uniformidade nacional conferido à educação não coincide com um ideal de ação para a transformação da

${ }^{29}$ Reportamo-nos à política de reabertura do processo imigratório, interditada pela lei de expulsão de estrangeiros no Brasil.

${ }^{30}$ Convém lembrar que a formação do Partido Trabalhista Brasileiro (PTB), do qual Vargas foi mentor intelectual, consistiu em uma das estratégias de "pulverizar" as tendências comunista, socialista e anarquista, dominantes entre o proletariado brasileiro. 
realidade já sedimentada, mas com o ideal de massificação e preservação das relações hegemônicas do Estado frente aos interesses populares.

\section{BIBLIOGRAFIA}

ACHARD, Pierre. Memória e produção discursiva do sentido. In: Papel da memória. Campinas, Pontes, 1999.

ADRIÃO, Pe. Pedro. Tradições clássicas da língua portuguesa. Porto Alegre, J. Pereira da Silva Editor, 1943.

AUROUX, Sylvain. Língua e hiperlíngua. Línguas e instrumentos lingüísticos. n. 1. Campinas, Pontes, 1998.

CARVALHO, J. Mesquita. Gramática e antologia nacional. Porto Alegre, Livraria do Globo, 1940.

FERREIRA, Maria Cristina L. Da ambigüidade ao equívoco: a resistência da língua nos limites da sintaxe e do discurso. Porto Alegre, Ed. da UFRGS, 2000.

GRAMSCI, Antônio. Concepção dialética da história. Rio de janeiro, Civilização Brasileira, 1989.

GUIMARÃES, Eduardo. Semântica do acontecimento. Campinas, Pontes, 2002.

HAROCHE, Claudine. Fazer dizer, querer dizer. São Paulo, Hucitec, 1992.

LÉLLIS, Raul Moreira. Português no ginásio: gramática e antologia. São Paulo, Nacional, 1950.

MACHADO FILHO, Aires da Mata. A correção na frase. Rio de Janeiro, Organização Simões, 1953.

MOTA, Otoniel. Lições de português. São Paulo, Nacional, 1941.

NASCENTES, Antenor. O idioma nacional na escola secundária. São Paulo, Companhia Editora Melhoramentos, 1935.

OITICICA, José L. Teoria da correlação. Rio de Janeiro, Organização Simões, 1952.

ORLANDI, Eni P. Terra à vista, discurso do confronto: velho e novo mundo. São Paulo, Cortez, 1990.

. Interpretação: autoria, leitura e efeitos do trabalho simbólico. Petrópolis, Vozes, 1996.

. Identidade lingüística escolar. IN: SIGNORINI, Inês (org). Língua(gem) e identidade. Campinas, Mercado das Letras, 1998. p.203-212. 
PÊCHEUX, Michel. Semântica e discurso; uma crítica à afirmação do óbvio. Campinas, Ed. da UNICAMP,1988.

PELLANDA, Nise C. Ideologia, educação \& repressão no Brasil pós64. Porto Alegre, Mercado Aberto, 1986.

RAJAGOPALAN, Kanavillil. O conceito de identidade em lingüística: é chegada a hora para uma reconsideração radical? IN: SIGNORINI, Inês (org). Língua (gem) e identidade. Campinas, Mercado das Letras, 1998. p21-43.

PEREIRA, Carlos Eduardo. Gramática expositiva; curso superior. São Paulo, Nacional, 1940.

RODRIGUES, Edgar. $O$ anarquismo: na escola, no teatro, na poesia. Rio de Janeiro, Achiamé, 1992.

Os libertários. Rio de Janeiro, VJR Ed., 1993.

SEQUEIRA, Cônego F.M. Bueno. A ação da analogia no português. Rio de Janeiro, Org. Simões, 1953.

TORRES, Artur de Almeida. Compêndio de língua portuguesa. São Paulo, Nacional, 1944.

VIANNA, Cibilis R. Reformas de base política nacionalista de desenvolvimento; de Getúlio a Jango. Rio de Janeiro, Civilização Brasileira, 1980.

WEFFORT, Francisco. O populismo na política brasileira. Rio de Janeiro, Paz e Terra, 1980.

ZANDWAIS, Ana. A confederação operária na Primeira República. In: INDURSKY, Freda \& CAMPOS, Maria do Carmo (orgs). Porto Alegre, Sagra-Luzzatto, 2000. p.141-50. (Col. Ensaios, 15)

\section{Periódicos}

A Plebe. São Paulo, 11.06.1921, p.2. (periódico anarquista)

A Vida. Rio de Janeiro, dezembro de 1914. (órgão da Confederação Operária Brasileira) 